\title{
Karakteristik Iklim Pulau Romang
}

\author{
Semuel Laimeheriwa \\ Program Studi Agroteknologi, Jurusan Budidaya Pertanian, Fakultas Pertanian, Universitas Pattimura \\ Jl. Ir. M. Putuhena, Kampus Poka Ambon 97233 \\ Email: laimeheriwasamuel@yahoo.co.id
}

\begin{abstract}
ABSTRAK
Iklim merupakan merupakan faktor produksi pertanian yang sangat dinamis dan beragam menurut ruang dan waktu. Oleh karena itu, agar pendekatan terhadap iklim/cuaca lebih berdaya guna dalam sektor pertanian, diperlukan suatu pemahaman yang lebih akurat terhadap karakteristik iklim melalui analisis dan interpretasi data iklim. Penelitian ini bertujuan untuk menyajikan karakteristik iklim Pulau Romang yang dapat dimanfaatkan dalam kegiatan di sektor pertanian. Penelitian ini menggunakan data iklim dari Stasiun Hujan Hila, Stasiun Iklim Lakuwahi, dan Stasiun Meteorologi Saumlaki. Analisis data dilakukan dengan menggunaan beberapa metode, yaitu (1) teknik rataan aljabar; (2) persamaan Oldeman, 1977; (3) sistem klasifikasi iklim Schmidt-Ferguson (1951) dan Oldeman (1975); dan (4) metode Modified Penman. Hasil analisis data menunjukkan bahwa Pulau Romang beriklim agak basah yang dicirikan oleh curah hujan rataan tahunan $2628 \mathrm{~mm}$; dimana nilai curah hujan peluang 75\% sebesar $1.794 \mathrm{~mm} / \mathrm{tahun}$. Berdasarkan sistem klasifikasi iklim Schmidt-Ferguson, Pulau Romang bertipe iklim B, dan berdasarkan sistem klasifikasi iklim Oldeman memiliki tipe iklim D1 dengan panjang periode pertumbuhan selama 11 bulan. Suhu udara tertinggi dalam bulan November-Desember dan terendah dalam bulan Juli-Agustus. Kelembaban udara tinggi selama musim hujan (Desember-Juni) dan rendah selama musim kemarau (Juli-November). Sebaliknya, lama penyinaran surya panjang selama musim kemarau dan pendek selama musim hujan. Evapotrasnpirasi potensial tahunan sebesar $1.771 \mathrm{~mm}$. Kecepatan angin rataan $1,7-4,0 \mathrm{~km} / \mathrm{jam}$, dan kecepatan angin maksimum $34-58 \mathrm{~km} / \mathrm{jam}$. Suhu udara di wilayah ini cenderung bertambah tiap tahunnya sebesar $0,0219^{\circ} \mathrm{C}$. Curah hujan tahunan periode belakangan ini (1989-2018) cenderung bertambah sebesar 5\% dibandingkan periode sebelumnya (1959-1988).
\end{abstract}

Kata kunci: Karakteristik iklim, Pulau Romang

\section{Climate Characteristics of Romang Island}

\begin{abstract}
Climate is a very dynamic agriculture production factor and varies according to space and time. Therefore, understanding climate characteristics by analysing and interpreting climate data is the needed in agriculture sector. The objective of the research was to present climate characteristics of Romang Island that are used in the agriculture sector. The climate data was obtained from Rainfall Station of Hila, Climate Station of Lakuwahi, and the Meteorology Station of Saumlaki. Rainfall data was analysed using several methods, namely (1) technique of algebra average, (2) Oldeman equation (1977), (3) Schmidt-Ferguson (1951) and Oldeman (1975) climate classification system; and (4) Modified Penman method. The result of data analysis indicated that climate of Romang Island is slightly wet characterized by annual average rainfall of $2.628 \mathrm{~mm}$, with $75 \%$ rainfall probability which is equal to $1.794 \mathrm{~mm} / \mathrm{year}$. The climate type of Romang Island is B and D1 according to Schmidt-Ferguson and Oldeman classification system, respectively with 11 months of growing season. The highest air temperature is found on November-December and the lowest on months July-August. Humudity is high during the rainy season (December-June) and low during dry season (July-November). While, the sun radiation is longer during dry season and shorter during the rainy season. The annual potential evapotrasnpirasi is $1.771 \mathrm{~mm}$, average wind speed ranges from 1,7 to 4,0 $\mathrm{km} /$ hour with the maximum 34 $58 \mathrm{~km} /$ hour. Annually air temperature in this region has been increased as much as $0,0219^{\circ} \mathrm{C}$, while rainfall experiences $5 \%$ increasing from period of (1959-1988) to (1989-2018) to the previous period.
\end{abstract}

Key words: climate characteristics, Romang Island 


\section{PENDAHULUAN}

Kegiatan berbagai sektor pembangunan seperti sektor pertanian, perkebunan, kehutanan, transportasi, pengairan, lingkungan hidup, pertambangan dan energi, mitigasi bencana dan lain-lain memerlukan informasi $\mathrm{iklim} /$ cuaca. Implikasinya, informasi iklim/ cuaca mempunyai nilai yang sangat strategis dalam pengambilan keputusan berkaitan dengan rencana dan evaluasi kegiatan berbagai sektor pembangunan.

Iklim/cuaca merupakan salah satu faktor produksi yang sangat dinamis, beragam, terbuka menurut ruang dan waktu serta sulit dikendalikan sehingga sering menjadi faktor pembatas produksi pertanian. Sifat iklim/cuaca tersebut agar pendekatannya di bidang pertanian lebih berdaya guna memerlukan suatu pemahaman yang lebih akurat terhadap karakteristik iklim/cuaca melalui analisis dan interpretasi data iklim/cuaca. Dalam prakteknya, iklim/cuaca tidak bisa dikendalikan dalam skala meso hingga makro (misalnya skala pulau, kepulauan, negara dan benua), maka langkah yang dapat dilakukan adalah melalui prakiraan atau peramalan iklim ${ }^{[1]}$.

Indonesia yang terletak antara dua benua (Asia dan Australia) dan dua Samudera (Pasifik dan Hindia) sangat mempengaruhi kondisi iklim Indonesia dengan berbagai ukuran dan topofisiografi pulau. Sistem cuaca dan iklim Indonesia sangat dipengaruhi oleh kondisi lokal seperti interaksi antar pulau, regional seperti sistem moonson, dan global seperti El-Nino ${ }^{[2]}$. Kondisi ini menyebabkan adanya keragaman pola iklim/cuaca pada berbagai wilayah di Indonesia. Keragaman pola iklim/cuaca pada berbagai wilayah menghendaki model prakiraan iklim/cuaca tidak bisa lagi diberlakukan secara umum dan bersifat "top down", tetapi harus secara sendiri-sendiri terutama pada skala lokal.

$$
\text { Pemanasan global yang terus }
$$
berlangsung hingga saat ini berdampak terhadap perubahan iklim dunia yang dicirikan oleh kejadian iklim ekstrim (seperti banjir dan kekringan) yang sering terjadi. Perubahan iklim sudah berdampak pada berbagai aspek kehidupan dan sektor pembangunan di Indonesia yang secara faktual sudah terjadi di tingkat lokal, regional maupun global. Implikasi kebijakannnya memerlukan pemahaman yang baik terhadap fenomena dan dampak perubahan iklim pada sektor pertanian dan strategi antsipasi harus dilakukan ${ }^{[3]}$.

Kejadian perubahan iklim yang telah terjadi, sementara terjadi, dan akan terus terjadi di masa datang mengisyaratkan bahwa penggunaan informasi iklim yang pernah ada perlu dimutakhirkan dengan menggunakan informasi data terbaru yang tersedia. Penggunaan data terbaru dalam perencanaan maupun implementasi berbagai kegiatan pembangunan termasuk pertanian menggambarkan iklim yang lebih representatif, sehingga dapat dijadikan acuan yang lebih obyektif untuk pengembangan wilayah secara umum termasuk pengembangan pertanian ${ }^{[4]}$.

Berdasarkan uraian di atas, maka penelitian ini dilakukan untuk menyajikan informasi klimatologi yang dapat dimanfaatkan dalam kegiatan berbagai sektor pembangunan termasuk sektor pertanian dalam arti luas. Pulau Romang diambil sebagai lokasi penelitian dengan mempertimbangkan dua hal penting tentang kondisi Pulau Romang saat ini dan yang akan datang, yaitu (1) sebagai salah satu daerah sentra produksi tanaman perkebunan (cengkeh dan pala) dan kehutanan (madu) di Kabupaten Maluku Barat Daya sehingga diperlukan informasi iklim untuk pengembangannya, dan (2) sebagai wilayah yang saat ini berlangsung aktivitas penambangan di beberapa lokasi sehingga diperlukan informasi iklim sebagai data dasar dalam memprakirakan besaran dampak lingkungan yang mungkin timbul akibat aktivitas penambangan tersebut.

Tujuan dari penelitian ini adalah mengkarakterisasi faktor iklim pada pulau 
Romang Kabupaten Maluku Barat Daya Provinsi Maluku.

\section{BAHAN DAN METODA Pengumpulan Data}

Penelitian ini menggunakan data iklim, terdiri dari: (1) data historis curah hujan dari Stasiun Hujan Hila Pulau Romang 10 tahun pengamatan 1959-1968, (2) data historis curah hujan dari Stasiun Hujan Saumlaki Pulau Yamdena 10 tahun pengamatan 1959-1968, (3) data klimatologi dari Stasiun Iklim Lakuwahi Pulau Romang periode 2009-2018, dan (4) data klimatologi Stasiun Meteorologi Saumlaki periode 1969-2008. Data curah hujan Daerah Saumlaki digunakan untuk membangkitkan/melengkapi data curah hujan Pulau Romang yang tidak tersedia, yaitu periode 1969-2008 menggunakan persamaan matematika sederhana ${ }^{[5,6]}$. Penggunaan data iklim Stasiun Meteorologi Saumlaki berdasarkan pertimbangan bahwa pola dan distribusi curah hujan bulanan antara kedua wilayah (Saumlaki dan Pulau Romang) adalah sama; yaitu pola hujan yang cenderung ekuatorial-bimodal dengan dua puncak hujan yang terjadi dalam bulan Desember/Januari dan bulan Mei, dan bulan terkering berlangsung dalam bulan Oktober. Panjang periode data curah hujan yang digunakan dalam analisis bahwa data curah hujan minimal 30 tahun pengamatan adalah representatif untuk menggambarkan kondisi iklim di suatu wilayah. sesuai dengan ${ }^{[7,8]}$.

\section{Analisis Data}

\section{a. Perhitungan nilai rataan unsur iklim}

Data iklim yang dikumpulkan (curah hujan, hari hujan, suhu udara;harian, maksimum dan minimum, kelembaban nisbi udara, penyinaran matahari serta kecepatan dan arah angin) akan dianalisis dengan metode statistika untuk mendapatkan nilai rataan (menggunakan teknik rataan aljabar); termasuk nilai maksimum dan minimumnya dengan persamaan : $\mathbf{X}_{\mathbf{b}}=\left(\sum \mathbf{X}_{\mathbf{i}}\right) / \mathrm{n}$, dimana $\mathrm{X}_{\mathrm{b}}=$ nilai rataan bulanan unsur iklim tertentu,
$\mathrm{X}_{\mathrm{i}}=$ nilai bulanan unsur iklim tertentu tahun ke-i, $\mathrm{n}=$ jumlah tahun pengamatan. Data yang akan ditampilkan untuk variabel arah angin disamping dalam bentuk tabel, juga dalam bentuk diagram windrose.

\section{a. Penentuan tipe iklim Schmidt- Ferguson dan Oldeman}

Penentuan tipe iklim Schmidt-Ferguson diawali dengan menentukan bulan basah (curah hujan $>100 \mathrm{~mm} /$ bulan) dan bulan kering (curah hujan $<60 \mathrm{~mm} / \mathrm{bulan}$ ) tahun demi tahun dari data time series curah hujan bulanan. Tahap berikutnya, tentukan nilai rataan bulan basah dan bulan kering tersebut yang selanjutnya digunakan untuk menghitung nilai $Q$ dengan rumus:

$$
Q=\frac{\text { Rataan Bulan Kering }}{\text { Rataan Bulan Basah }} \times 100 \%
$$

Hasil perhitungan nilai Q kemudian digunakan untuk menentukan tipe iklim Pulau Romang dengan merujuk pada Segitiga SchmidtFergusson ${ }^{[9]}$.

Penentuan tipe iklim Oldeman dilakukan dengan menggunakan data rataan curah hujan bulanan. Analisis data untuk penentuan tipe iklim diawali dengan menentukan bulan basah (curah hujan $>200$ $\mathrm{mm} /$ bulan) dan bulan kering (curah hujan $<100 \mathrm{~mm} / \mathrm{bulan}$ ) berturut-turut, dilanjutkan dengan penentuan tipe iklim Pulau Romang menggunakan Tabel Kriteria Oldeman dan/atau Segitiga Iklim Oldeman ${ }^{[10]}$.

\section{b. Penentuan curah hujan peluang $\mathbf{7 5 \%}$}

Penentuan nilai curah hujan berpeluang $75 \%$ untuk dilampaui menggunakan persamaan $\mathbf{P}_{75}=\mathbf{0 . 8 2} \mathbf{P}-\mathbf{3 0}$, dimana $\mathrm{P}_{75}=$ curah hujan bulanan peluang $75 \%$, dan $\mathrm{P}=$ curah hujan rataan bulanan ${ }^{[11,12]}$.

\section{c. Pendugaan evepotranspirasi potensial (ETp) \\ Data ETp bulanan di wilayah ini tidak} tersedia, sehingga perlu diduga menggunakan metode Modified Penman dengan persamaan $\mathbf{E T p}=\mathbf{c}[(\mathbf{W} \cdot \mathbf{R n}+(\mathbf{1}-\mathbf{W}) \cdot \mathbf{f}(\mathbf{U}) \cdot($ ea-ed $)$, dimana : $\mathrm{ETp}=$ evapotranspirasi potensial 
(mm); c= faktor koreksi Penman (bergantung rasio kecepatan angin siang dan malam, kelembaban relatif maksimum, dan radiasi gelombang pendek, nilainya berkisar antara 0,27-1,0; W=faktor pembobot (bergantung pada suhu dan ketinggian tempat), nilainya berkisar antara $0,43-0,89 ; \mathrm{Rn}=$ total radiasi neto $(\mathrm{Rn}=0,75 \mathrm{RS}-\mathrm{Rnl}) ; \mathrm{Rs}=$ radiasi gelombang pendek yang datang ( $R s=0,25+0,50 \mathrm{n} / \mathrm{N})$; $\mathrm{n}=$ lama penyinaran yang terukur; $\mathrm{N}=$ lama penynaran maksimum yang mungkin; Rnl=radiasi neto gelombang panjang; $\mathrm{f}(\mathrm{U})=$ fungsi angin $: \mathrm{f}(\mathrm{U})=0,27(1+\mathrm{U} / 100)$; $\mathrm{U}=$ kecepatan angin pada ketinggian 2 meter; dan $\mathrm{f}($ ea-ed $)=$ defisit tekanan uap. Nilai ETp hasil perhitungan adalah nilai harian ( $\mathrm{mm} /$ hari) sehingga untuk mendapatkan nilai ETp bulanan maka ETp harian dikalikan dengan jumlah hari dari setiap bulannya ${ }^{[13]}$.

\section{d. Analisis tren perubahan iklim}

Terkait dengan perubahan iklim, dua unsur iklim utama yang umumnya dibicarakan atau dikaji berbagai pihak adalah suhu udara dan curah hujan. Analisis tren suhu udara menggunakan data 30 tahun periode 19892018 yang danalisis menggunakan regresi sederhana. Selanjutnya analisis tren curah hujan menggunakan data curah hujan 60 tahun periode 1959-2018 yang dibagi menjadi dua periode, yaitu Periode I: 1959-1988 dan periode II:1989-2018; dimana tren (perubahan) ditentukan dengan membandingkan nilai curah hujan rataan antara kedua periode tersebut.

\section{HASIL DAN PEMBAHASAN}

\section{Curah Hujan dan Tipe Iklim}

Hasil analisis data seri curah hujan bulanan (Tabel 1 dan Gambar 1) menunjukkan bahwa rataan curah hujan tahunan di Pulau Romang cukup tinggi $(2.627 \mathrm{~mm})$ dengan puncak hujan terjadi dalam dua bulan, yaitu pada bulan Desember (rataan $438 \mathrm{~mm}$ ) dan bulan Mei (rataan $360 \mathrm{~mm}$ ), sedangkan bulan terkering berlangsung dalam bulan Oktober (rataan $52 \mathrm{~mm}$ ). Jumlah hari hujan rataan sebesar 177 hari/tahun dengan kisaran terendah 7 hari pada bulan Oktober hingga tertinggi 22 hari dalam bulan Desember dan Mei. Kondisi curah hujan bulanan pada tingkat peluang $75 \%$ untuk dilampaui berkisar antara paling rendah $13 \mathrm{~mm}$ dalam bulan Oktober hingga tertinggi $329 \mathrm{~mm}$ dalam bulan Desember dengan nilai tahunan $1.794 \mathrm{~mm}$.

Tabel 1. Rataan bulanan curah hujan dan hari hujan, dan curah hujan pada tingkat peluang $75 \%$ untuk dilampaui di Pulau Romang

\begin{tabular}{lccc}
\hline Bulan & $\begin{array}{c}\text { Curah Hujan } \\
(\mathbf{m m})\end{array}$ & Hari Hujan & $\begin{array}{c}\text { Curah Hujan } \\
\text { Peluang 75\%(mm) }\end{array}$ \\
\hline Januari & 229 & 21 & 158 \\
Februari & 177 & 15 & 115 \\
Maret & 113 & 14 & 63 \\
April & 211 & 14 & 143 \\
Mei & 360 & 22 & 265 \\
Juni & 287 & 15 & 205 \\
Juli & 174 & 14 & 113 \\
Agustus & 234 & 11 & 162 \\
September & 178 & 10 & 116 \\
Oktober & 52 & 7 & 13 \\
November & 174 & 12 & 113 \\
Desember & 438 & 22 & 329 \\
Setahun & $\mathbf{2 . 6 2 7}$ & $\mathbf{1 7 7}$ & $\mathbf{1 . 7 9 4}$ \\
\hline
\end{tabular}


Sumber : Diolah/dibangkitkan dari (1) data curah hujan Stasiun Hila-P.Romang, (2) data curah hujan Stasiun Hujan Saumlaki, (3) data curah hujan Stasiun Iklim Lakuwahi-P.Romang Periode 2009-2018 dan (3) data curah hujan Stasiun Meteorologi Saumlaki Periode 1989-2008

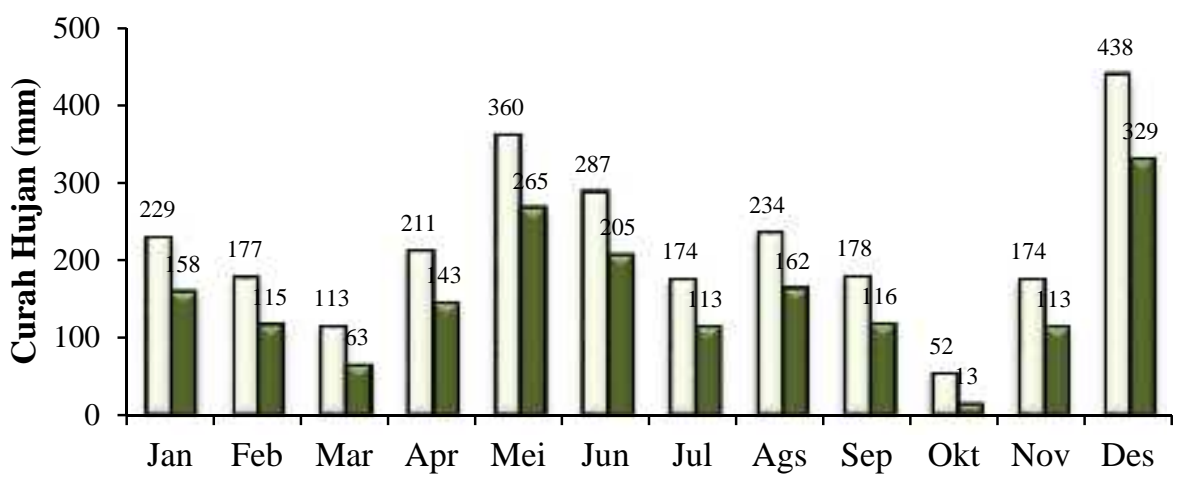

$\square \mathrm{P}$

口P75

Gambar 1. Pola dan distribusi curah hujan bulanan ( $\mathrm{P}=$ rataan, $\mathrm{P} 75=$ peluang $75 \%$ ) di Pulau Romang

Berdasarkan sistem klasifikasi iklim yang dibuat oleh Schmidt-Ferguson ${ }^{[9]}$, Pulau Romang termasuk dalam Tipe Iklim B, yaitu daerah basah dengan vegetasi hutan hujan tropis dengan nilai $\mathrm{Q}=32,9 \%$; rataan bulan kering (curah hujan $<60 \mathrm{~mm} /$ bulan) selama 2,6 bulan dan rataan bulan basah (curah hujan $>100 \mathrm{~mm} /$ bulan) selama 7,9 bulan. Selanjutnya menurut sistem klasifikasi iklim yang dibuat oleh Oldeman ${ }^{[10]}$, Pulau Romang memiliki Tipe Iklim D1, yang dicirikan oleh banyaknya bulan basah (curah hujan $>200$ $\mathrm{mm} /$ bulan) selama 3 bulan berturut-turut yaitu April, Mei, Juni dan bulan kering (curah hujan $<100 \mathrm{~mm} /$ bulan) selamam 1 bulan yaitu Oktober, dengan panjang periode pertumbuhan selama 11 bulan.

\section{Suhu Udara, Kelembaban Udara, Lama Penyinaran, dan Evapotranspirasi}

Kondisi bulanan suhu udara, kelembaban nisbi udara, lama penyinaran surya, dan evepotranspirasi potensial di Pulau Romang seperti yang disajikan pada Tabel 2.

Tabel 2. Kondisi bulanan suhu udara, kelembaban udara, lama penyinaran surya, dan evapotranspirasi potensial di Pulau Romang

\begin{tabular}{|c|c|c|c|c|c|c|}
\hline \multirow{2}{*}{ Bulan } & \multicolumn{3}{|c|}{ Suhu Udara $\left({ }^{\circ} \mathrm{C}\right)$} & \multirow{2}{*}{$\begin{array}{l}\text { Kelembaban } \\
\text { Nisbi } \\
(\%)\end{array}$} & \multirow{2}{*}{$\begin{array}{c}\text { Lama } \\
\text { Penyinaran } \\
(\%)\end{array}$} & \multirow{2}{*}{$\begin{array}{c}\text { Evapotranspirasi } \\
\text { Potensial } \\
(\mathrm{mm})\end{array}$} \\
\hline & Harian & Maksimum & Minimum & & & \\
\hline Januari & 27,3 & 31,3 & 23,4 & 86 & 58 & 161 \\
\hline Februari & 27,5 & 31,7 & 23,3 & 85 & 60 & 150 \\
\hline Maret & 27,3 & 31,6 & 23,2 & 85 & 65 & 152 \\
\hline April & 27,5 & 31,7 & 23,2 & 84 & 58 & 144 \\
\hline Mei & 27,0 & 30,3 & 23,4 & 87 & 51 & 123 \\
\hline Juni & 25,9 & 28,7 & 22,7 & 83 & 55 & 130 \\
\hline Juli & 25,2 & 27,9 & 22,1 & 82 & 61 & 132 \\
\hline Agustus & 25,3 & 28,4 & 22,0 & 79 & 74 & 136 \\
\hline September & 26,4 & 30,3 & 22,4 & 79 & 77 & 158 \\
\hline Oktober & 27,2 & 31,4 & 22,9 & 77 & 80 & 177 \\
\hline
\end{tabular}




\begin{tabular}{llllllc}
\hline Nopember & 28,0 & 32,2 & 23,7 & 80 & 68 & 153 \\
Desember & 27,9 & 32,4 & 23,5 & 86 & 52 & 155 \\
\hline Tahunan & $\mathbf{2 6 , 9}$ & $\mathbf{3 0 , 6}$ & $\mathbf{2 3 , 0}$ & $\mathbf{8 3}$ & $\mathbf{6 3}$ & 1.771 \\
\hline \multicolumn{7}{l}{ Sumber : Diolah dari (1) Data Klimatologi Stasiun Iklim Iklim Lakuwahi-Romang Periode 2009-2018, dan (2) Data Klimatologi } \\
\multicolumn{7}{r}{ Stasiun Meteorologi Saumlaki Periode 2004-2018 }
\end{tabular}

\section{a. Suhu udara}

Rataan suhu udara harian di Pulau Romang berkisar antara yang paling rendah $25,2{ }^{0} \mathrm{C}$ dan $25,3{ }^{0} \mathrm{C}$ pada bulan Juli dan Agustus hingga tertinggi $27,9^{\circ} \mathrm{C}$ dan $28,0^{\circ} \mathrm{C}$ pada bulan November dan Desember dengan nilai tahunan $26,9^{\circ} \mathrm{C}$. Suhu udara rataan maksimum tertinggi $32,4^{\circ} \mathrm{C}$ dan $32,2^{\circ} \mathrm{C}$ terjadi dalam bulan November dan Desember dengan nilai tahunan $30,6^{\circ} \mathrm{C}$. Rataan suhu udara minimum terendah $22,0^{\circ} \mathrm{C}$ dan $22,1^{\circ} \mathrm{C}$ terjadi dalam bulan Juli dan Agustus dengan nilai tahunan $23,0^{\circ} \mathrm{C}$.

Kondisi suhu udara bulanan tersebut di atas berkorelasi positif dengan radiasi surya yang tiba di permukaan bumi. Terkait dengan data lama penyinaran surya, terlihat bahwa suhu udara maksimum tertinggi (NovemberDesember) terjadi 1-2 bulan setelah radiasi surya maksimum di bulan September-Oktober, sebaliknya suhu udara minimum terendah (Juli-Agustus) terjadi 1-2 bulan setelah radisi surya minimum di bulan Mei-Juni. Terjadi keterlambatan ini disebabkan karena pengaruh kuat dari perairan (laut) yang memiliki sifat "lama menjadi panas dan lama pula menjadi dingin". Panas jenis air yang lebih tinggi dari benda padat lainnya seperti daratan menyebabkan perairan dapat menyimpan panas yang lebih besar dan lebih lama dibandingkan daratan.

\section{b. Kelembaban udara}

Kelembaban nisbi udara bulanan di Pulau Romang berkisar antara yang paling rendah dalam periode bulan Juli sampai November (rataan 79\%) hingga tertinggi dalam periode bulan Desember hingga Juni (rataan 85\%). Selama musim hujan kelembaban nisbi udara biasanya tinggi (83$87 \%$ ), dan selama musim kemarau kelembaban nisbi udara biasanya rendah (77$82 \%$ ) dengan nilai rataan tahunan $83 \%$.

\section{c. Lama penyinaran}

Kondisi penyinaran surya sangat bergantung pada presentase penutupan awan yang dipengaruhi oleh kondisi hujan. Lamanya surya bercahaya cerah di Pulau Romang berkisar dari yang terendah pada bulan Mei $(51 \%=4,1$ jam/hari) ketika curah hujan maksimum hingga tertinggi pada bulan Oktober $(80 \%=6,4$ jam/hari) ketika curah hujan minimum. Selama periode musim hujan lama penyinaran rendah (rataan $57 \%=4,6$ jam/hari) akibat persentase penutupan awan yang tinggi, sebaliknya selama periode musim kemarau lama penyinaran relatif tinggi (rataan $72 \%=5,8$ jam/hari) karena langit umumnya cerah.

\section{d. Evapotranspirasi potensial}

Evapotrasnpirasi potensial ditentukan oleh kondisi unsur iklim seperti suhu, kelembaban, kecepatan angin dan radiasi surya; disamping letak astronomis wilayah (lintang dan bujur). Nilai evapotranspirasi potensial bulanan di Pulau Romang berkisar antara yang paling rendah $123 \mathrm{~mm}$ dalam bulan Mei hingga tertinggi $177 \mathrm{~mm}$ dalam bulan Oktober dengan nilai tahunan $1771 \mathrm{~mm}$.

\section{Kecepatan dan Arah Angin}

Angin merupakan salah satu unsur iklim yang berperan penting dalam interaksi antara permukaaan (darat dan laut) dan atmosfer. Kondisi angin di suatu lokasi atau tapak mendapat perhatian tidak hanya dalam penelitian meteorologi/klimatologi saja tetapi juga dalam penelitian bidang ilmu lainnya, termasuk pertanian.

Secara global kondisi angin di Pulau Romang sangat dipengaruhi oleh sirkulasi umum angin moonson serta pengaruh lokal; yaitu posisi geografis dan topofisiografi pulau. Kondisi bulanan kecepatan dan arah angin di Pulau Romang berdasarkan hasil pengamatan 
Stasiun Iklim Lakuwahi Pulau Romang periode 2009-2018 seperti yang disajikan pada Tabel 3.

Tabel 3. Kondisi angin di Pulau Romang

\begin{tabular}{lcccc}
\hline \multirow{2}{*}{ Bulan } & \multicolumn{2}{c}{ Rataan } & \multicolumn{2}{c}{ Maksimum } \\
\cline { 2 - 5 } & $\begin{array}{c}\text { Kecepatan } \\
(\mathrm{km} / \text { jam })\end{array}$ & Mata Angin & $\begin{array}{c}\text { Kecepatan } \\
(\mathrm{km} / \text { jam })\end{array}$ & Mata Angin \\
\hline Januari & $\mathbf{3 . 8}$ & SBD & $\mathbf{5 8}$ & STG \\
Februari & $\mathbf{2 . 9}$ & SBD & $\mathbf{5 2}$ & SBD \\
Maret & 2.3 & BD & 50 & STG \\
April & 1.7 & BL & 37 & BL \\
Mei & $\mathbf{3 . 0}$ & UBL & 45 & UBL \\
Juni & $\mathbf{3 . 2}$ & TG & 42 & BL \\
Juli & $\mathbf{4 . 0}$ & S & $\mathbf{5 2}$ & UBL \\
Agustus & $\mathbf{2 . 9}$ & S & 47 & UBL \\
September & 2.2 & TG & 51 & BL \\
Oktober & 1.9 & BL & 39 & BL \\
Nopember & 1.2 & BL & 34 & UBL \\
Desember & 1.5 & BD & 35 & SBD \\
\hline
\end{tabular}

Sumber : Diolah dari Data Klimatologi Stasiun Lakuwahi Pulau Romang Periode Pengamatan 2009-2018 Keterangan:

\begin{tabular}{|c|c|c|c|c|c|c|}
\hline $\mathrm{BD}$ & Barat Daya & S & Selatan & $\mathrm{BL}$ & : & Barat Laut \\
\hline SBD & : Selatan-Barat Daya & TG & Tenggara & UBL & : & Utara Barat Laut \\
\hline STG & : Selatan-Tenggara & & & & & \\
\hline
\end{tabular}

\section{a. Kecepatan angin rataan dan arah terbanyak}

Ketika bertiup angin timuran yang dominan di Pulau Romang (April-September), kecepatan angin berkisar antara $1,7 \mathrm{~km} / \mathrm{jam}$ pada bulan April hingga 4,0 km/jam pada bulan Juli. Selama periode Oktober-Maret saat bertiup angin baratan yang dominan, kecepatan angin berkisar antara $1,2 \mathrm{~km} / \mathrm{jam}$ pada bulan November hingga $3,8 \mathrm{~km} / \mathrm{jam}$ pada bulan Januari. Kondisi kecepatan angin rataan tersebut berdasarkan skala Beaufort digolongkan sebagai "angin sangat lemah (1$11 \mathrm{~km} / \mathrm{jam}) "$.

Selama setahun arah tiupan angin dominan berasal dari tiga arah, yaitu: (1) Barat Daya-Selatan Barat Daya berlangsung dalam bulan Desember s.d Maret, (2) Barat LautUtara Barat Laut berlangsung dalam bulan April-Mei dan Oktober-November, dan (3) Selatan-Tenggara berlangsung dalam bulan Juni s/d September. Diagram arah angin terbanyak pada kondisi kecepatan angin rataan di Pulau Romang seperti yang disajikan pada Gambar 2.

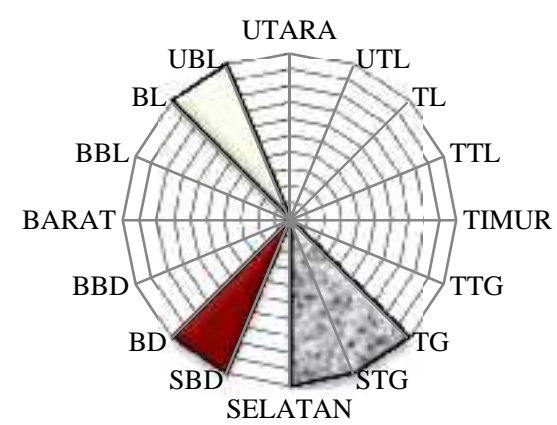

EDes, Jan, Feb, Mar $\quad \square$ Apr, Mei, Okt, Nov

口Jun, Jul, Ags, Sep

Gambar 2. Arah angin dominan selama setahun pada kondisi kecepatan angin rataan di Pulau Romang 


\section{b. Kecepatan angin maksimum dan arahnya}

Data series angin periode 2009-2018 menunjukkan bahwa kecepatan angin maksimum tiap bulannya yang pernah terjadi di Pulau Romang berkisar antara yang terendah $34 \mathrm{~km} / \mathrm{jam}$ pada bulan November dari arah Utara Barat Laut hingga yang tertinggi 58 $\mathrm{km} / \mathrm{jam}$ dalam bulan Januari dari arah Selatan Tenggara. Kondisi kecepatan angin maksimum yang terjadi dalam bulan Januari, Februari, Maret, Juli, dan September berdasarkan skala Beaufort dikategorikan sebagai "angin kencang" (50-61 km/jam), sedangkan dalam bulan lainnya termasuk kategori "angin sedang sampai angin kuat (20$49 \mathrm{~km} / \mathrm{jam})$ ". Kondisi arah angin pada kecepatan maksimum di Pulau Romang seperti yang disajikan pada Gambar 3.

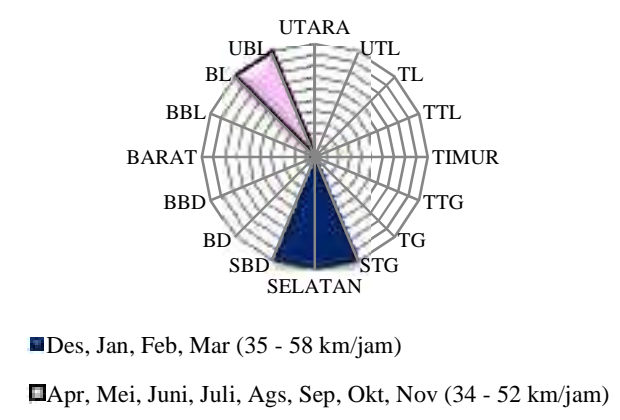

Gambar 3. Arah angin pada kecepatan maksimum di Pulau Romang

\section{Tren Suhu Udara}

Berdasarkan hasil pengolahan data observasi BMKG mulai dari tahun 1981-2018, secara umum suhu di Indonesia baik suhu minimum, rataan, dan maksimum memiliki tren yang bernilai positif dengan besaran yang bervariasi sekitar $0.03{ }^{\circ} \mathrm{C}$ setiap tahunnya. Ini bisa diartikan bahwa suhu akan mengalami kenaikan $0.03{ }^{\circ} \mathrm{C}$ setiap tahunnya sehingga dalam 30 tahun lokasi tersebut akan mengalami kenaikan sebesar $0.9^{\circ} \mathrm{C}(\mathrm{BMKG}$, 2019). Penggunaan regresi sederhana untuk analisis tren perubahan suhu udara di Kota Semarang; hasilnya suhu udara cenderung mengalami kenaikan yang signifikan, yaitu sebesar $0,0257^{\circ} \mathrm{C}$ per tahun ${ }^{[14]}$.
Hasil analisis regresi menunjukkan bahwa perubahan suhu udara di wilayah Pulau Romang dalam periode 30 tahun terakhir (1989-2018) cenderung meningkat setiap tahunnya sebesar $0,0219^{\circ} \mathrm{C}$ (Gambar 4). Diproyeksikan pada 30 tahun mendatang suhu udara di wilayah ini akan mengalami kenaikan sebesar $0,7^{\circ} \mathrm{C}$. Adanya kecenderungan peningkatan suhu udara ini akan berdampak pada terjadinya peningkatan deplesi air tanah. Kondisi ini berisiko terhadap berkurangnya ketersediaan air tanah terutama ketika dibarengi dengan kejadian kekeringan (kemarau panjang) atau anomali iklim ElNino. Disamping itu, diperkirakan akan terjadi eksplosi beberapa organisme pengganggu tanaman yang akan berpengaruh negatif terhadap hasil tanaman.

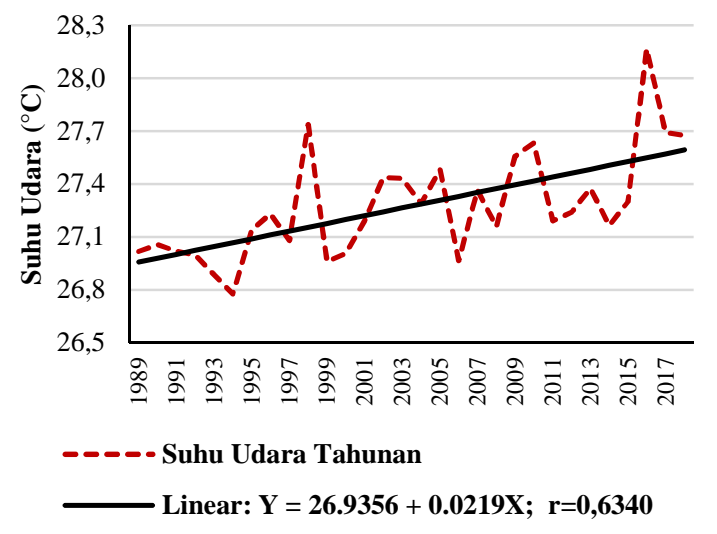

Gambar 4. Tren perubahan suhu udara di Pulau Romang

\section{Tren Curah Hujan}

Beberapa hasil penelitian beberapa peneliti $[15,16]$ menunjukkan bahwa ada kecenderungan terjadi perubahan curah hujan (peningkatan atau penurunan) pada berbagai daerah di Indonesia dalam periode belakangan ini dibandingkan dengan periode sebelumnya. Hasil analisis data curah hujan Pulau Romang periode 60 tahun (1959-2018) menunjukkan bahwa telah terjadi peningkatan curah hujan dalam periode belakangan ini (1989-2018) dibandingkan periode sebelumnya (19591988); baik selama musim hujan maupun musim kemarau. Peningkatan curah hujan tahunan cenderung tidak mengalami 
perubahan yang signifikan, yaitu hanya 126 $\mathrm{mm}$ atau 5,0\% (Tabel 4). Curah hujan cenderung berkurang dalam bulan Januari sebesar $37 \mathrm{~mm}(13,9 \%)$ dan bulan Juli $44 \mathrm{~mm}$ $(20,2 \%)$, sedangkan 10 bulan lainnya curah hujan cenderung bertambah antara $1-62 \mathrm{~mm}$ atau $0,3-62,5 \%$. Persentase peningkatan curah hujan terbesar terjadi selama musim kemarau (Juli-November) sebesar 10,5\%, sedangkan selama musim hujan (DesemberJuni) peningkatannnya hanya sebesar $2,8 \%$.

Tabel 4. Perubahan curah hujan di Pulau Romang (perbandingan antara Periode I:1959-1988 dengan Periode II:1989-2018)

\begin{tabular}{lccccccccccccc}
\hline Periode & \multicolumn{10}{c}{ Curah Hujan (mm) } \\
\cline { 2 - 11 } & Jan & Feb & Mar & Apr & Mei & Jun & Jul & Ags & Sep & Okt & Nov & Des & Setahun \\
\hline I:1959-1988 & 266 & 162 & 109 & 207 & 342 & 286 & 218 & 172 & 161 & 32 & 152 & 395 & 2502 \\
II:1989-2018 & 229 & 177 & 113 & 211 & 360 & 287 & 174 & 234 & 178 & 52 & 174 & 438 & 2628 \\
& & & & & & & & Perubahan & & & \\
mm & -37 & 15 & 4 & 4 & 18 & 1 & -44 & 62 & 17 & 20 & 22 & 43 \\
Persen (\%) & $-13,9$ & 9,3 & 3,7 & 1,9 & 5,3 & 0,3 & $-20,2$ & 36,0 & 10,6 & 62,5 & 14,5 & 10,9 & 5,0 \\
\hline
\end{tabular}

\section{KESIMPULAN}

Pulau Romang beriklim agak basah dengan rataan curah hujan tahunan $2.628 \mathrm{~mm}$, dengan kisaran nilai bulanan mulai dari yang terendah $52 \mathrm{~mm}$ dalam bulan Oktober hingga tertinggi $438 \mathrm{~mm}$ dalam bulan Desember dan $360 \mathrm{~mm}$ dalam bulan Mei. Kondisi curah hujan bulanan pada tingkat peluang $75 \%$ berkisar antara paling rendah $13 \mathrm{~mm}$ dalam bulan Oktober hingga tertinggi $329 \mathrm{~mm}$ dalam bulan Desember dengan nilai tahunan $1.794 \mathrm{~mm}$. Terdapat dua puncak curah hujan (Desember dan Mei) mencirikan wilayah ini memiliki pola hujan yang cenderung ekuatorialbimodal. Berdasarkan sistem klasifikasi iklim Schmidt-Ferguson, Pulau Romang bertipe iklim B, dan berdasarkan sistem klasifikasi iklim Oldeman memiliki tipe iklim D1 dengan panjang periode pertumbuhan selama 11 bulan. Suhu udara tertinggi dalam bulan November-Desember dan terendah dalam bulan Juli-Agustus. Kelembaban udara tinggi selama musim hujan (Desember-Juni) dan rendah selama musim kemarau (JuliNovember). Kecepatan angin dari terendah $1,7 \mathrm{~km} / \mathrm{jam}$ pada bulan April hingga tertinggi 4,0 km/jam dalam bulan Juli; berasal dari tiga arah dominan (dari Barat Daya, dari arah Barat Laut, dan Selatan sampai Tenggara).
Kecepatan angin maksimum tiap bulannya berkisar antara $34-58 \mathrm{~km} / \mathrm{jam}$ yang umumnya berasal dari dua arah, yaitu Barat Laut sampai Utara Barat Laut dan Selatan Barat Daya sampai Selatan Tenggara.

Ketersediaan informasi iklim dan agroklimat di setiap wilayah sangat diperlukan untuk dimanfaatkan di berbagai sektor pembangunan, termasuk pertanian. Pendekatan iklim (agroklimat) dalam bidang pertanian mempunyai arti penting untuk perencanaan dan pengembangan wilayah, penentuan komoditas dan paket teknologi pertanian, serta perencanaan dan pengelolaan sistem usaha tani.

\section{DAFTAR PUSTAKA}

[1] Laimeheriwa, S. 2014. Analisis tren perubahan curah hujan pada tiga wilayah dengan pola hujan yang berbeda di Provinsi Maluku. Jurnal Budidaya Pertanian 10 (2): 71-78.

[2] Irianto, G dan Suciantini. 2006. Anomali iklim: faktor penyebab, karakteristik dan antisipasinya. Jurnal Iptek Tanaman Pangan 2:101-121

[3] Tim Sintesis Kebijakan. 2008. Dampak perubahan iklim terhadap sektor pertanian, serta strategi antisipasi dan teknologi 
adaptasi. Jurnal Pengembangan Inovasi Pertanian 1 (2):138-140.

[4] Irianto, G., Amien, I, dan E. Surmaini. 2004. Keragaman iklim sebagai peluang diversifikasi. Dalam Sumberdaya lahan Indonesia dan pengelolaannya; Puslitbangtanak, BPPP Deptan, Bogor. Hal. 67-95.

[5] Nangimah, S.L., Laimeheriwa, S dan R. Tomasoa. 2018. Dampak fenomena El Nino dan La Nina terhadap keseimbangan air lahan pertanian dan periode tumbuh tersedia di Daerah Waeapo Pulau Buru. Jurnal Budidaya Pertanian 14(2): 66-74.

[6] Laimeheriwa, S., Pangaribuan, M, dan M. Amba. 2019. Analisis fenomena El Nino dan dampaknya terhadap neraca air lahan di Pulau Ambon. Jurnal Budidaya Pertanian 15(2): 111-118.

[7] Schulz, E.F. 1980. Problem and applied hydrology. Water Res. Publ., Fort Collins, Colorado.

[8] Manik, T.K. 2014. Klimatologi dasar; Unsur iklim dan proses pembentukan iklim. Graha Ilmu, Yogyakarta.

[9] Schmidt, F.H and H.A. Ferguson. 1951. Rainfall types based on wet and dry period ratios for Indonesia with Western New Guinea. Kementerian DMG-Perhubungan, Jakarta.
[10] Oldeman, L.R, 1975. An agroclimatic map of Java. Contr. Centr. Res. Inst. Agric., 17, Bogor. 22p.

[11] Oldeman, L.R. 1977. Climate of Indonesia. In Proc. of $6^{\text {th }}$ Asian Pacific Weed Sci.Soc.Conf., Jakarta. p:14-30.

[12] Oldeman, L.R and M. Frere. 1982. A study of agroclimatology of the humid tropics of Southeast Asia. FAO/Unesco/WMO Intragency Project on Agroclimatology. Rome.

[13] Pruitt, W.O and J. Doorenbos. 1977. Guidelines for predicting crop water requerement. FAO of Uneted States. Rome.

[14] Suryadi, Y., D.N. Sugianto dan Hadiyanto. 2017. Identifikasi perubahan suhu dan curah hujan serta proyeksinya di Kota Semarang. Proceeding Biology Education 14(1): 241246.

[15] Boer, R., Baharsjah, J.S., Las, I, dan H. Pawitan. 2003. Analisis Kerentanan dan Adaptasi Terhadap Keragaman dan Perubahan Iklim. Simposium Meteorologi Pertanian VI. 9-10 September 2003, Bogor, Indonesia. pp. 36-49.

[16] Misnawati dan M. Perdanawanti. 2019. Tren curah hujan ekstrem Pulau Sumatera tahun 1981-2010. Jurnal Agromet 33(1): 41-51. 